ENTREPRENEURSHIP AND SUSTAINABILITY ISSUES

ISSN 2345-0282 (online) http://jssidoi.org/jesi/ 2020 Volume 8 Number 1 (September)

http://doi.org/10.9770/jesi.2020.8.1(15)
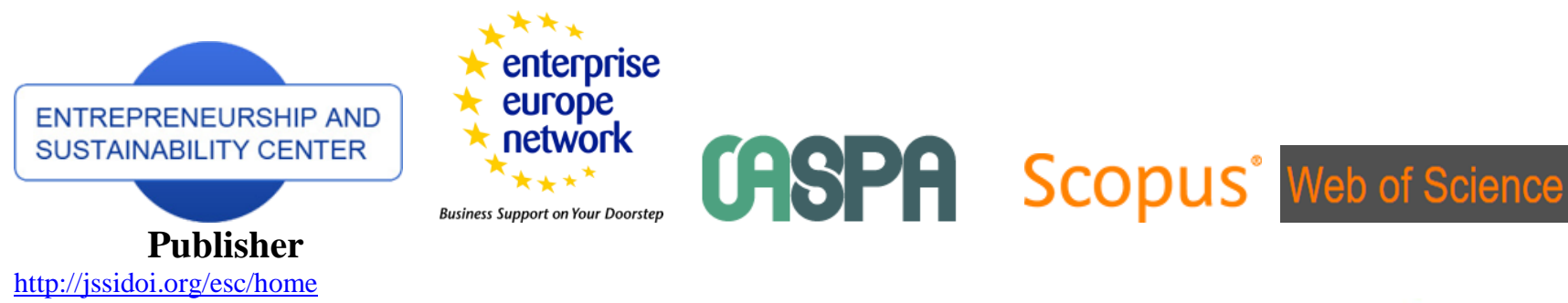

http://jssidoi.org/esc/home

Business Support on Your Doorstep

1) Clarivate

Analytics

\title{
FORMATION AND IMPLEMENTATION OF REGIONAL TARGETED AGRO-INDUSTRIAL COMPLEX DEVELOPMENT PROGRAMS TOWARDS INTEGRATED RURAL DEVELOPMENT
}

\author{
Olga Yu. Voronkova ${ }^{1 *}$, Parviz A. Kurbanov ${ }^{2}$, Alexander A. Fomin ${ }^{3}$, \\ Pavel S. Babkin ${ }^{4}$, Elena A. Matveeva ${ }^{5}$, Alevtina A. Kharina ${ }^{6}$ \\ ${ }^{1 *}$ Altai State University, Lenin Ave., 61, 656049, Barnaul, Russian Federation \\ ${ }^{2}$ Western Caspian University, Istiqlaliyyat st., 31, AZ0001, Baku, Azerbaijan \\ ${ }^{3}$ State University of Land Use Planning, Kazakova st., 15, 105064, Moscow, Russian Federation \\ ${ }^{4}$ State University of Land Use Planning, Kazakova st., 15, 105064, Moscow, Russian Federation \\ ${ }^{5}$ Sechenov First Moscow State Medical University, 119991, Moscow, Trubetskaya st., 8-2, Russian Federation \\ ${ }^{6}$ Perm State University, 614990, Bukireva st., 15, Perm, Russian Federation \\ E-mails:*lolka2004@yandex.ru
}

Received 19 February 2020; accepted 30 June 2020; published 30 September 2020

\begin{abstract}
The paper discusses current issues related to the formation and implementation of regional targeted programs for the development of the agro-industrial complex (AIC), and also assesses their impact on the sustainable development of rural areas of the region. As an example, a regional target program has been developed and economically justified to involve fallow and unused lands in agricultural production turnover. The author's methodology for the formation and implementation of regional target programs for the development of the agro-industrial complex is presented. On the basis of this methodology, a pilot project of the regional target program "Involving Arable Lands Not Used for Their Intended Purpose in the Altai Territory for Sustainable Rural Development for the Period of 2020-2025" has been developed. Based on the strategy for the development of agricultural production in the Altai Territory, as well as in the context of the implementation of the draft regional target program developed by the authors, the forecasted production values of the main agricultural products of the Altai Territory for the period of 2020-2030 are presented. In the forecast calculations, the portion of the planned organic agricultural production is highlighted, the effectiveness of program measures is assessed, some conclusions are drawn on the feasibility of regional targeted programs towards sustainable rural development.
\end{abstract}

Keywords: target programs; sustainable development; unused arable land; rural areas; efficiency; agribusiness strategy; forecast

Reference to this paper should be made as follows: Voronkova, O.Yu., Kurbanov, P.A., Fomin, A.A., Babkin, P.S., Matveeva, E.A, Kharina, A.A. 2020. Formation and implementation of regional targeted agro-industrial complex development programs towards integrated rural. Entrepreneurship and Sustainability Issues, 8(1), 1238-1247. http://doi.org/10.9770/jesi.2020.8.1(15)

JEL Classifications: Q01, R11, Q56

Additional disciplines regional development 


\section{ENTREPRENEURSHIP AND SUSTAINABILITY ISSUES}

ISSN 2345-0282 (online) http://jssidoi.org/jesi/

2020 Volume 8 Number 1 (September)

http://doi.org/10.9770/jesi.2020.8.1(15)

\section{Introduction}

The Russian Federation has all the necessary resources for the further development of agricultural production, including today's highly efficient production of organic products - these are long-term agricultural traditions, vast areas of agricultural land resources, as well as a relatively low level of intensification and chemicalization of agricultural production in comparison with industrialized countries. So, for example, if the average level of chemicalization in the EU countries, expressed in the indicator "fertilizer application", is $196 \mathrm{~kg}$ of active ingredient per 1 hectare of agricultural land, on average in Russia this indicator does not exceed $43 \mathrm{~kg}$, and in the largest arable land area - the Altai Territory $-4.8 \mathrm{~kg}$ per 1 hectare of arable land (Tatarkin, Policyn, 2015).

Rural territories play a significant role in shaping the economy of the region and the way of life of the population, for example, agriculture accounts for more than $19 \%$ of gross regional product against $6-7 \%$ in Russia. About $44 \%$ of the total national population lives in rural territories of the region. The Altai Territory has huge agricultural potential, ranking first in Russia in terms of arable land (6.5 million hectares), of which more than $75 \%$ are fertile chernozems (Kryukov et al., 2018). In terms of gross agricultural output, the region is in the first place among the regions of the Siberian Federal District and is in the top ten among the regions of the Russian Federation. The contribution of the region's agriculture to the solution of the national food security problem is $4 \%$ of all-Russian grain production, $3 \%$ of sunflower, $15 \%$ of flax, $5 \%$ of milk, $3 \%$ of potato, about $3 \%$ of meat and eggs, about $2 \%$ of sugar beets and vegetables (Voronkova et al., 2018; Yemelyanov et al., 2018; Tikhomirov et al., 2018).

For completeness of comparative analysis of the level of development of agriculture in Russia, we consider similar indicators of Azerbaijan. The territory of the Azerbaijan Republic is 86.6 thousand square meters. km., which is almost 200 times less than the territory of Russia. Land structure: $12 \%$ forest, $1.6 \%$ water basin, $52.3 \%$ land suitable for agriculture, $34.1 \%$ other land. Of the total land area (8.7 million ha), agricultural land is 4.6 million ha. Of these, more than 1.8 million hectares are arable land, 2 million hectares are occupied by summer and winter pastures, part of the agricultural land is occupied by perennial plantations (Agriculture in Azerbaijan, 2020). Thus, despite the significant difference in the total area of the territories of Russia and Azerbaijan, the ratio of the area of land suitable for agriculture to the total area of the territory does not differ much. As a result of the foregoing, it becomes relevant and significant to identify the relationship between the sustainable development of rural areas of the region and the formulation and implementation of regional targeted programs for the development of the agro-industrial complex (AIC).

\section{Methods}

The theoretical and methodological basis of the research is the works by domestic and foreign scientists on the sustainable development of rural areas, agricultural production in agricultural regions of the country; the academic studies and recommendations of the Russian Academy of Agricultural Sciences, the regulations of the Russian Federation, the decrees of the President and resolutions of the Government of the Russian Federation, regulatory legal acts of the constituent entities of the federation. The methodological basis was a systematic approach, which allowed for comprehensiveness and a targeted view. The following research methods were also used in this study: monographic, analytical, abstract-logical, computational-constructive, economic-statistical, extrapolation.

\section{Results}

The main goal of the implementation of the regional target development program is to increase production efficiency in certain segments of its target orientation through targeted support of the subsidy recipients, as well as continuous monitoring by authorized regional governing bodies of the targeted and rational use of the provided budgetary resources. In the process of research, as well as on the basis of studying domestic and foreign 
experience in implementing targeted development programs, a mechanism was created making it possible to optimally form the regional targeted development programs for the AIC, as well as assess their effectiveness (Figure 1).

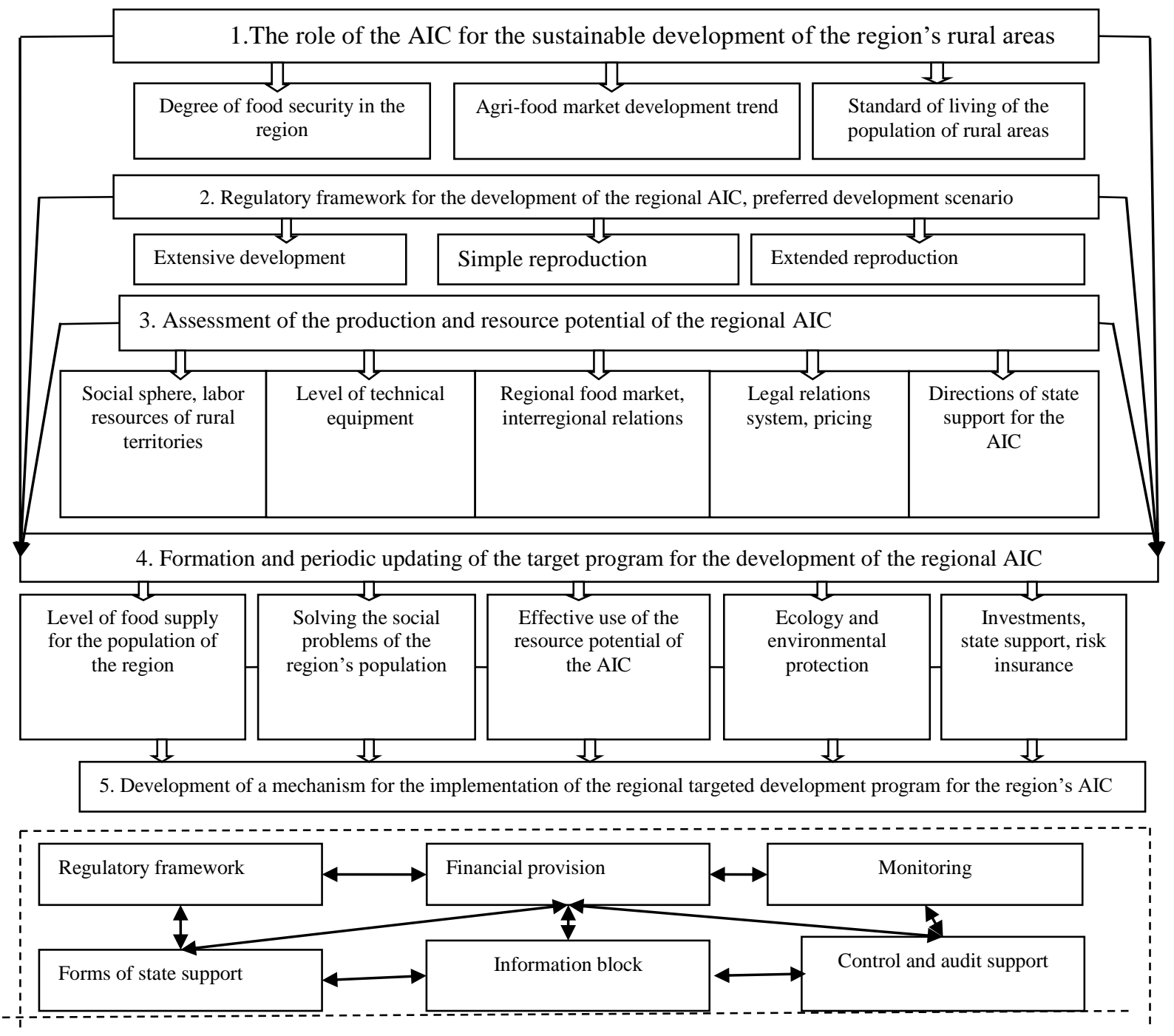

Fig. 1. The mechanism for the formation and implementation of the regional target program for the development of the AIC towards sustainable rural development Source: the authors

Thus, arable land is the main resource of production in the agricultural production of rural areas. Over the past three decades, a significant amount of productive arable land has been removed from agricultural production, which has negatively affected both the volume of agricultural production and rural employment (Kovalenko, 2012; Miloserdov, 2014; Zhuchenko, 2012). In order to create an enabling environment for the sustainable development of rural territories in agricultural regions, it is necessary to involve unused arable land in the agricultural production process (Lysenko, 2008). Stimulation of agricultural producers, increasing the efficiency of their activities on additional involvement into agricultural production of arable land not used for its intended purpose, is assumed through the mechanism for implementing regional targeted development programs (Polushkina, 2012). 


\section{ENTREPRENEURSHIP AND SUSTAINABILITY ISSUES}

ISSN 2345-0282 (online) http://jssidoi.org/jesi/ 2020 Volume 8 Number 1 (September) http://doi.org/10.9770/jesi.2020.8.1(15)

The group of authors has developed a pilot project of the regional target program "Involving Arable Lands Not Used for Their Intended Purpose in the Altai Territory for Sustainable Rural Development for the Period of 20202025". The main provisions of the proposed regional target program are aimed at a more complete and efficient use of arable land by agricultural producers, increasing their efficiency, increasing the production of agricultural products in the Altai Territory, as well as increasing the level of employment and socio-economic well-being of residents of rural territories of the region (Korableva et al., 2018).

Expected results of the implementation of the regional target program "Involving Arable Lands Not Used for Their Intended Purpose in the Altai Territory for Sustainable Rural Development for the Period of 2020-2025":

1) an increase in the share of arable land used for its intended purpose by 2025 to $100 \%$ relative to the level of 2020;

2) involvement in agricultural production turnover of unused arable land with an area of 217 thousand hectares and fallow land with an area of 336 thousand hectares for the purpose of sustainable development of rural territories of the region;

3) formation of an effective mechanism for the implementation of regional targeted programs for the development of agriculture towards sustainable development of rural areas;

4) reproduction of soil fertility of arable land, environmental protection;

5) rational planning of production uses of arable and fallow land resources involved in the production turnover.

The total land area in the Altai Territory as of January 1, 2019 is 11,534.4 thousand ha, of which 10,596 thousand ha are farmlands. Of the total agricultural land area, arable land covers 6,542.1 thousand ha, fodder land - 3,731.1 thousand ha. According to statistics, the area of unused arable land in 2019 amounted to 217 thousand ha, the area of fallow land - 336 thousand ha (Melgui et al., 2018). Consequently, the reserve fund for increasing the sown area of the region is $\mathbf{5 5 3}$ thousand ha. In order to more efficiently use arable land, it is necessary to develop a set of measures to stimulate agricultural enterprises in the region to engage arable land that they do not use (Podprugin, 2012). The intended use of arable land is an important measure to increase soil fertility, increase the value of land resources, create new jobs, improve the quality of life of the rural population, the social and economic development of rural areas, and is also of great environmental importance (Altukhov, 2018; Alferova, 2015; Klochko et al., 2016). The mechanism of subsidizing part of the costs associated with the involvement of unused arable land in production includes the provision to agricultural producers of compensation for the reimbursement of part of the costs of involving unused arable land in the production turnover at the rate of 3,000 rubles for 1 hectare of arable land introduced into agricultural circulation that has not been used for its intended purpose for more than three years. The amount of compensation is calculated on the basis of the average market price of 60 liters of diesel fuel per 1 hectare of fallow arable land, this amount is minimally necessary for the necessary agricultural activities (Table 1).

Table 1. Performance indicators for the implementation of the draft regional target program for the period of 2020-2025 (forecast values)

\begin{tabular}{|c|c|c|c|c|c|c|c|}
\hline \multirow{2}{*}{ No. } & \multirow{2}{*}{ Indicators } & \multicolumn{6}{|c|}{ Year } \\
\hline & & 2020 & 2021 & 2022 & 2023 & 2024 & 2025 \\
\hline 1 & Reserve fund of unused arable resources, thousand ha & 553 & 496 & 424 & 359 & 298 & 249 \\
\hline 2 & $\begin{array}{l}\text { Area of unused and unclaimed arable land allocated as } \\
\text { land shares, thousand ha }\end{array}$ & 411 & 411 & 250 & 135 & 70 & - \\
\hline 3 & $\begin{array}{l}\text { Area of arable land to be involved into agricultural } \\
\text { circulation, thousand ha }\end{array}$ & 35 & 49 & 68 & 65 & 60 & 50 \\
\hline 4 & $\begin{array}{l}\text { Area of arable land in unsatisfactory agrotechnical } \\
\text { condition, thousand ha }\end{array}$ & 790 & 790 & 773 & 764 & 746 & 749 \\
\hline 5 & $\begin{array}{l}\text { Total area of arable land used for its intended purpose, } \\
\text { thousand hectares }\end{array}$ & 6,317 & 6,384 & 6,656 & 6,521 & 6,573 & 6,636 \\
\hline
\end{tabular}

Source: the authors' research 


\section{ENTREPRENEURSHIP AND SUSTAINABILITY ISSUES}

ISSN 2345-0282 (online) http://jssidoi.org/jesi/ 2020 Volume 8 Number 1 (September) http://doi.org/10.9770/jesi.2020.8.1(15)

It is necessary to provide for the annual development by agricultural organizations of plans where the planned structure of land use should be presented by each agricultural organization. Program activities also envisage the annual involvement of about $10 \%$ of the total area of unused arable land in agricultural production, and the effectiveness of the use of the arable land put into circulation should be evaluated annually based on data provided by land user organizations.

Table 2 presents the estimated financial support of the regional target program "Involving Arable Lands Not Used for Their Intended Purpose in the Altai Territory for Sustainable Rural Development for the Period of 20202025". The amount of funding for program activities is determined on the basis of the distribution of powers between the regional budget, as well as the municipal share of budget financing and extrabudgetary sources (Table 2).

Table 2. Program measures for the period of 2020-2025 (resources and terms of implementation of each event), million rubles

\begin{tabular}{|c|c|c|c|c|c|c|c|c|c|c|c|c|c|c|c|c|c|c|}
\hline Measure & \multicolumn{18}{|c|}{ Year } \\
\hline \multicolumn{19}{|c|}{ Task 1. Assessment of unused arable resources (allocated as land shares) } \\
\hline \begin{tabular}{|l|} 
Identification of \\
unused arable land \\
allocated as land \\
shares
\end{tabular} & & & & 161 & & 161 & 115 & & 115 & 65 & & 65 & 60 & & 60 & & & \\
\hline \multicolumn{19}{|c|}{ Task 2. Preservation of the natural environment and rational use of arable land } \\
\hline $\begin{array}{l}\text { Land use } \\
\text { structure } \\
\text { optimization }\end{array}$ & \multicolumn{18}{|c|}{ At the expense of funds provided for the operation of administrative bodies of state and municipal authorities } \\
\hline $\begin{array}{l}\text { Total } \\
\text { according to } \\
\text { the program }\end{array}$ & 71 & 26 & 45 & 523 & 134 & 389 & 504 & 144 & 360 & 420 & 130 & 286 & 395 & 124 & 270 & 175 & 102 & 173 \\
\hline
\end{tabular}

Source: the authors' research

The effectiveness of the implementation of the proposed project of the regional target program will be assessed by identifying the completeness and quality of the implemented program activities, the degree of achievement of the goals and objectives. The program activities are aimed at the sustainable development of rural areas of the country's agrarian regions by increasing the efficiency of agricultural production and creating the preconditions for ensuring food security in both the region under consideration and the Russian Federation as a whole by increasing the volume of agricultural production (Danilov-Danilian, 2003; Kolesova, 2015; Prokhorova, et al., 2016; Voronkova et al., 2020; Ziyadin, 2012).

The implementation of the draft regional target program should be based on legal, organizational, financial, informational and methodological support and support from the authorized bodies of regional power and management (Snitch, 2011). Program activities should be open in nature and implemented through wide information accessibility for agricultural producers, in particular, through the official website of the regional government and websites of executive authorities in municipalities. The effectiveness of the implementation of the project of the regional target program is assessed in accordance with the main objectives of the program and contributes to: 
1) identification of deviations of the current indicators of the implementation of program activities from the planned and approved ones;

2) identification of internal and external causes of deviations from the plan and their consideration in the formation of program activities for the next planning period;

3) adoption of measures aimed at the integrated implementation of indicators, as well as the current and final results of the activities of the regional target program;

4) taking measures to improve the quality of planning.

The following criteria can be noted for evaluating the effectiveness of the implementation of the regional target program:

1) the degree of implementation of planned program activities;

2) the level of achievement of the intended results;

3) the degree of compliance of the results obtained with the actual costs incurred for the implementation of program activities;

4) the compliance of operational indicators with the level of certain indicators for the implementation of program activities;

5) the completeness of the implementation of program activities.

Evaluation of the effectiveness degree in the implementation of the activities of the regional target program is based on the established target indicators presented in Table 1.

To assess the effectiveness of the production-related use of arable land and fallow land involved in agricultural turnover, the executive authorities of the municipalities of the region need to quickly monitor the condition of land resources put into turnover with the financial support of the regional target program in order to make decisions on suspension of subsidies for any agricultural organization in case if negative factors are found in land use, expressed in a decrease in soil fertility, deterioration in the quality state of arable land, reduced productivity, and in the case of the absence of a visible positive results in achieving the goals of sustainable development of rural areas.

\section{Discussion}

Based on the strategy for the development of agriculture in the Altai Territory until 2025, as well as the regional target program "Involving Arable Lands Not Used for Their Intended Purpose in the Altai Territory for Sustainable Rural Development for the Period of 2020-2025" developed in the research process, the forecast values of agricultural production in the Altai Territory for the period until 2025 have been calculated based on the extrapolation method. The forecast is based on an analysis of agricultural production volumes in the Altai Territory for the period of 2000-2019, then the forecast was formed by extrapolating the current trend of a gradual increase in production volumes, also taking into account the annual involvement of additional arable land into agricultural production turnover, and, accordingly, agricultural output from the given area (Table 3). 
Table 3. Predicted values of agricultural production in the Altai Territory, taking into account the implementation of program activities for the period of 2020-2025, thousand tons

\begin{tabular}{|c|c|c|c|c|c|c|}
\hline \multirow[t]{2}{*}{ Indicators } & \multicolumn{6}{|c|}{ Year } \\
\hline & 2020 & 2021 & 2022 & 2023 & 2024 & 2025 \\
\hline Cereal crops & 4,100 & 4,150 & 4,300 & 4,500 & 4,600 & 4,800 \\
\hline $\begin{array}{l}\text { including produced on arable land, } \\
\text { additionally involved in turnover }\end{array}$ & 67 & 95 & 170 & 240 & 319 & 380 \\
\hline Flax & 7.9 & 8.5 & 9.4 & 9.5 & 9.7 & 10.1 \\
\hline $\begin{array}{l}\text { including produced on arable land, } \\
\text { additionally involved in turnover }\end{array}$ & 0.3 & 0.5 & 0.7 & 0.8 & 0.9 & 1.0 \\
\hline Sugar beet & 505 & 640 & 695 & 720 & 765 & 800 \\
\hline $\begin{array}{l}\text { including produced on arable land, } \\
\text { additionally involved in turnover }\end{array}$ & 7 & 15 & 24 & 39 & 46 & 60 \\
\hline Sunflower & 303 & 320 & 335 & 354 & 370 & 395 \\
\hline $\begin{array}{l}\text { including produced on arable land, } \\
\text { additionally involved in turnover }\end{array}$ & 3 & 5 & 9 & 15 & 28 & 36 \\
\hline Potatoes & 857 & 869 & 876 & 880 & 886 & 900 \\
\hline $\begin{array}{l}\text { including produced on arable land, } \\
\text { additionally involved in turnover }\end{array}$ & 7 & 12 & 24 & 46 & 72 & 89 \\
\hline
\end{tabular}

Source: the authors' research

In the strategically foreseeable period (2020-2025), it is planned to increase the share of agricultural products of the Altai Territory produced on arable land, additionally involved in turnover in the cereals group up to $7.9 \%$, flax up to $10 \%$, sugar beet up to $7.5 \%$, sunflower up to $9.1 \%$, potatoes up to $9.9 \%$ of the total agricultural production in the region.

As a result, an increase in the cost of gross agricultural output in comparable prices of 2020 by 2025 is forecasted to reach 182 billion rubles, or $155 \%$ compared to 2015 ; the profitability level of agricultural organizations is planned to be increased up to $20 \%$, in comparison with the estimated indicator of $2015-8.7 \%$ (Table 4).

Table 4. Target indicators for the development of agriculture in the Altai Territory, taking into account the implementation of program activities for the period of 2020-2025

\begin{tabular}{|c|c|c|c|c|c|c|}
\hline \multirow{2}{*}{ Indicators } & \multicolumn{6}{|c|}{ Year } \\
\hline & 2020 & 2021 & 2022 & 2023 & 2024 & 2025 \\
\hline $\begin{array}{l}\text { Value of gross agricultural output, billion rubles, at } \\
\text { comparable prices of } 2020\end{array}$ & 121 & 129 & 136 & 144 & 152 & 161 \\
\hline Production index, as $\%$ of 2020 & 100.0 & 106.6 & 112.4 & 119.0 & 125.6 & 133.1 \\
\hline Profitability of agricultural organizations, $\%$ & 9.9 & 12.5 & 13.1 & 14.2 & 15.5 & 16.8 \\
\hline
\end{tabular}

Source: the authors' research 


\section{ENTREPRENEURSHIP AND SUSTAINABILITY ISSUES}

ISSN 2345-0282 (online) http://jssidoi.org/jesi/

2020 Volume 8 Number 1 (September)

http://doi.org/10.9770/jesi.2020.8.1(15)

\section{Conclusions}

The study identified that the rural territories of the country's agrarian regions possess the necessary climatic conditions, labor, resource and land potential towards sustainable development goals. An in-depth analysis and assessment of the possibility of applying the world experience of sustainable rural development in conjunction with the existing system of Russian agricultural land use are serious prerequisites for strategic development and strengthening the position of the AIC in the national economy.

The mechanism of formulation and implementation of the regional target program for the development of AIC towards sustainable development of rural territories, justified and presented in the study, made it possible to develop a draft regional target program "Involving Arable Lands Not Used for Their Intended Purpose in the Altai Territory for Sustainable Rural Development for the Period of 2020-2025". The main activities of the program are aimed at a more complete and efficient use of arable land by agricultural organizations, increasing production efficiency in agriculture, as well as increasing the volume of agricultural production in the Altai Territory. So, according to program measures until 2025, 217 thousand hectares of arable land and 336 thousand hectares of fallow land not used for their intended purpose and not claimed by the owners of land shares will be involved in agricultural production turnover.

According to the results of the study, the maximum amount of subsidiary support until 2025 was identified on the basis of a reasonable standard for arable land introduced into agricultural production, not used for its intended purpose, in the amount of 3,000 rubles per hectare for doing agricultural works. The developed methodology for operational monitoring of the effectiveness of the use of arable land introduced into turnover will allow the municipal authorities of the region to quickly monitor the state of arable land and fallow land in order to decide on the suspension of subsidies for any agricultural organization when identifying some factors of inefficient land use.

Based on the strategy for the development of agricultural production in the Altai Territory, as well as taking into account the developed draft regional target program "Involving Arable Lands Not Used for Their Intended Purpose in the Altai Territory for Sustainable Rural Development for the Period of 2020-2025", forecast values of agricultural production of the region for 2020-2025 have been calculated. Target indicators for the development of agriculture in the Altai Territory have been substantiated, in accordance with the implementation of the programrelated activities.

The prevailing natural and climatic conditions of rural territories of the country's agrarian regions, as well as the concentration of land, material, financial and labor resources towards sustainable development, not only open up some additional opportunities for agricultural production but also will reduce the dependence on products imports, and will enhance the level of quality and environmental safety of products, the development of diversification of agricultural production and the socio-economic development of rural areas of the country's agricultural regions.

\section{References}

Alferova, T.V. 2015. Conceptual modeling of the category of «sustainable development». Journal of Economic Theory, 4, 46-52.

Altukhov, A.I. 2008. Food security - an important factor in the stability of Russia. Economics of agriculture of Russia, 12, 13-16.

Danilov-Danilian, V.I. 2003. Sustainable development. Theoretical and methodological analysis. Economics and Mathematical Methods, 8 (24), 123-135. 


\section{ENTREPRENEURSHIP AND SUSTAINABILITY ISSUES}

ISSN 2345-0282 (online) http://jssidoi.org/jesi/ 2020 Volume 8 Number 1 (September)

http://doi.org/10.9770/jesi.2020.8.1(15)

Klochko, E.N., Shishkin, V.O., Shichiyakh R.A., Sychanina S.N., Smolentsev V.M. 2016. Targeted program management of the fruit and berry sub-complex of Krasnodar Region. International Review of Management and Marketing, 6(1), 40-46.

Kolesova, Yu. N. 2015.Strategy of sustainable development of rural areas. Young scientist, 8, 392-394.

Kovalenko, E. G. 2012. Problems and mechanisms of development of rural territorie. Fundamental research, 3-3, 687-690.

Kryukov V.A. 2018. The study of the economy of Siberia: continuity and complexity. Region: Economics and sociology, 2(98), 3-32.

Korableva, O. N., Kalimullina, O. V., \& Mityakova, V. N. 2018. Innovation activity data processing and aggregation based on ontological modelling. Paper presented at the 2018 4th International Conference on Information Management, ICIM 2018, 1-4. https://doi.org/10.1109/INFOMAN.2018.8392659

Lysenko, E. G. 2008. Ecological and economic problems of agriculture. Economics of agriculture of Russia, 2, 68-73.

Melgui, A. E., Kuznetsova, O. N., Butler, Yu. A. 2018. Stimulation of socio-economic development of agriculture in Russia. Agribusiness: Economics, management, 8, 19-26.

Miloserdov, V. V. 2014. Causes of food dependence in Russia. Economy of agricultural and processing enterprises, 3, 6-11.

Podprugin, M. O. 2012. Sustainable development of the region: the concept, the basic approaches and the factors. Journal of Russian entrepreneurship, 24, 214-221.

Polushkina, T. M. 2012. Formation of a rational system of state regulation of agrarian sector of economy meeting the requirements of cost-effective agricultural policy. Basic research, 9-4, 976-980.

Prokhorova, V.V., Klochko, E.N., Kolomyts, O.N., Gladilin, A.V. 2016. Prospects of the agro-industrial complex development: Economic diversification, business development, mono-industry town strengthening and expansion. International Review of Management and Marketing, 6(6), 159-164.

Snitch, V. F. 2011. Formation of institutions of regional agri-food market. Advances of modern natural science, 2, 138-142.

Tatarkin, A. I., Policyn, S. N. 2015. The regional dimension of food security in Russia. AIC: Economy, management, 12, 3-9.

Tikhomirov, A.I., Fomin, A.A. 2018. Macroeconimic factors in realizing export potential for animal production. International Agricultural Journal, 61(3), 4.

Voronkova, O.Y., Ovchinnikov, Y.L., Avdeev, Y.M., Fomin, A.A., Penkova, A.N., Zatsarinnaya, E.I. 2020. Land Resource Management in the Agro-Industrial Sector of Russia. Talent Development and Excellence, 12(3s), 422-431.

Voronkova, O.Y., Sycheva, I.N., Shpakova, R.N., Pashkova, E.Y., Poltarykhin A.L. 2018. Economic mechanism of regulating land relations in the agricultural sector of Russia. European Research Studies Journal, 21(4), 280-291.

Yemelyanov, V., Yemelyanova, N., \& Nedelkin, A. 2018. Neural network for decision support to determine the operating mode of lined equipment. Paper presented at the MATEC Web of Conferences, 224 https://doi.org/10.1051/matecconf/201822404005

Zhuchenko, A. A. 2012. Challenges of the XXI century of world and domestic food security. Agro-Food policy of Russia, 1, 6-8.

Ziyadin, S. 2012. Prospects for information marketing within processing industry of agroindustrial sector in the Republic of Kazakhstan. Actual Problems of Economics, 136(10), 429-436.

Agriculture in Azerbaijan. 2020, January 29. In Wikipedia, the free encyclopedia. Retrieved May 19, 2020, from https://en.wikipedia.org/wiki/Agriculture_in_Azerbaijan 


\section{ENTREPRENEURSHIP AND SUSTAINABILITY ISSUES}

ISSN 2345-0282 (online) http://jssidoi.org/jesi/ 2020 Volume 8 Number 1 (September) http://doi.org/10.9770/jesi.2020.8.1(15)

Olga Yurievna VORONKOVA, Doctor of Economics, Professor of management, business organization and innovation Department, Altai state University. Has the status of an expert of the Eurasian technological platform "Technologies of food and processing industry of agriculture - healthy food". Research interests: sustainable development of territories, innovation, technological and social entrepreneurship, "green" economy.

ORCID ID: https://orcid.org/0000-0002-3106-4643

Parviz Akhmed KURBANOV, Ph.D. in Economics, Professor, Head of the Department of Finance and Accounting, Western Caspian University, Baku, AZ0001, Azerbaijan Republic.

P.A. Kurbanov published more than 100 scientific articles, 5 study guides, 2 textbooks and 1 monograph on economic issues and problems of labor organization and leasing relations in the transport and agricultural industry. Research interests: economic issues in entrepreneurship and regional development, leasing relations in the agricultural industry.

ORCID ID: https://orcid.org/0000-0002-2124-8780

Alexander Anatolyevich FOMIN, PhD in Economics, Professor of the Department of Economic Theory and Management, State university of land use planning, Deputy Chairman of the Committee of the chamber of Commerce and industry of the Russian Federation for the development of agriculture, editor-in-chief of the "International agricultural journal". Research interests: land management, sustainable development of territories, research of agricultural markets, integrated development of rural areas.

ORCID ID: http://orcid.org/0000-0002-3881-8348

Pavel Sergeyevich BABKIN, Director of the State Budget Institution of the Moscow Region "Center for Cadastral Assessment". In addition to direct guidance on conducting state cadastral valuation, he participates in the development of proposals for improving the subject legislation. Implementation of data processing based on neural networks. He is a member of the State Certification Commission at State University of Land Use Planning. Research interests: agro-industrial complex; integrated rural development; state cadastral valuation; neural networks; land use planning.

ORCID ID: https://orcid.org/0000-0001-7456-283X

Elena Aleksandrovna MATVEEVA, Senior Lecturer, Department of orthopaedic dentistry I.M. Sechenov First Moscow State Medical University, Russian Federation, 119991, Moscow, Trubetskaya st., 8-2, Currently engaged in teaching clinical dentistry for students and postgraduate and research on rehabilitation of patients with anomalies of the lip and palate. Research interests: comprehensive development of rural areas, development of medicine in rural areas, the formation and implementation of regional targeted programs for the development of medicine in rural areas.

ORCID ID: https://orcid.org/0000-0002-2105-8880

Alevtina Aleksandrovna KHARINA, Postgraduate Student, Accounting, Audit and Economic Analysis Department, Perm State University. The teacher of the Komi-Permyak agrotechnical College. Research interests: Economics, Finance, Management, Accounting, Controlling.

ORCID ID: http://orcid.org/0000-0002-1923-4806

Register for an ORCID ID:

https://orcid.org/register

Copyright (C) 2020 by author(s) and VsI Entrepreneurship and Sustainability Center

This work is licensed under the Creative Commons Attribution International License (CC BY).

http://creativecommons.org/licenses/by/4.0/

(c) (i) Open Access 